\title{
Nursing Scheduling Mode and Experience from the Medical Teams in Aiding Hubei Province During the COVID-19 Outbreak: A Systematic Scoping Review of 17 Studies
}

\author{
Xiaochun Zhang' \\ De-Sheng Huang $\mathbb{D}^{2,3}$ \\ Peng Guan $\mathbb{D}^{2}$ \\ 'Department of Pulmonary and Critical \\ Care Medicine, The First Hospital of \\ China Medical University, Shenyang, \\ I I000 I, People's Republic of China; \\ ${ }^{2}$ Department of Epidemiology, School of \\ Public Health, China Medical University, \\ Shenyang, II O122, Liaoning, People's \\ Republic of China; ${ }^{3}$ Department of \\ Mathematics, School of Fundamental \\ Sciences, China Medical University, \\ Shenyang, II0122, Liaoning, People's \\ Republic of China
}

\begin{abstract}
Introduction: Due to COVID-19 outbreak, since January 24, 2020, national medical teams from across the country and the armed forces have been dispatched to aid Hubei. The present review was designed to timely summarize the existing frontline information about nursing scheduling mode with special focus on the length of shifts with the aim to contribute to improve the nurses' job satisfaction and the quality of nursing services.

Methods: Articles from Jan 2020 to October 2020 were retrieved from China National Knowledge Infrastructure, Wanfang Data and Weipu Information, with the terms "COVID19", “designated hospital", "Hubei-assisted", "makeshift hospital”, "nursing", "nursing shift", "whole-system takeover" and variations of these, in the title and abstract fields and the Boolean combinations of these words as the retrieval strategy.

Results: Seventeen journal articles have been included in the target field, from the nurses in aiding Hubei Province, four kinds of shift length, 2-hour (h), 3-h, 4-h and 6-h shift have been considered, the main nursing scheduling mode adopted in designated hospitals for COVID19 patients was dynamic scheduling based on workload, flexible scheduling based on working hours, workload and the number of critically ill patients admitted, humanized scheduling based on the daily reported health status of the nurses, and professional-integrated scheduling according to the professional distribution of nurses on the basis of four-hour shift length, and in makeshift hospitals for mild patients, the scheduling mode was 6-h based correspondingly. Conclusion: The descriptive results of the present systematic review shed light on the challenges and practical solutions of nursing scheduling mode in the context of crossregional medical assistance. Additionally, the present systematic review could provide the academic community of nurses, nurse managers and administrators with baseline information and scientific productions from the content's points of view in the target field.
\end{abstract}

Keywords: nursing scheduling, shift work, nursing management, systematic review

\section{Introduction}

Since January 24, 2020, a total of 346 medical teams composed of 42,600 medical workers and 965 public health workers from across China and the armed forces have been dispatched to aid Hubei in fighting COVID-19. ${ }^{1}$ Among the medical workers who risked their health and lives to aid Hubei, the nurses accounted for a major part and played a crucial role. With sometimes scarce medical resources and difficult working environment in the early stage of aid to Hubei, these medical
Correspondence: Peng Guan

Department of Epidemiology, School of Public Health, China Medical University, Shenyang, II0I22, Liaoning, People's Republic of China

Email pguan@cmu.edu.cn 
workers encountered many tremendous challenges in ward division, disinfection, isolation and the deployment of nursing staff, they were at greater risk of experiencing high levels of psychological distress and suffering. That kind of emergency required a quick reorganization of human resources. The timely summarized experience and lessons in the field of patient care and nursing management provided by the medical team are of great importance for improving emergency management strategy. ${ }^{2-4}$

In the above-mentioned background, the present systematic review was designed to collect the information about nursing scheduling mode with special focus on the length of shifts. The work organization characteristics have been proved to have a significant impact on the outcome in nursing. ${ }^{5-7}$ When the nurses in the national medical rescue teams came from different provinces, different hospitals and different specialties, how to arrange shifts reasonably is therefore prudent. ${ }^{89}$ When considering the issues of personal safety protection, the nurses' unfamiliarity with the environment, unfamiliarity with the medical equipment and even unfamiliarity with the doctors or patients' local dialects, the length of each shift and the adjustment of the shift length are the important components of the deployment of nursing human resources in this major public health emergency. ${ }^{10,11}$

In addition to the timely summary of experience and timely submission by the nurse teams in aiding Hubei, Chinese journals in related professional fields have also made corresponding concerted efforts to deal with relevant submissions as soon as possible to disseminate relevant experience for medical staff across the country as the reference. In view of the impressive efforts by the nurses, the description of the organization of nursing shift patterns will help to call the attention to the special considerations during the cross-regional medical assistance process.

\section{Materials and Methods Study Selection}

Articles from Jan 2020 until October 2020 were retrieved from China National Knowledge Infrastructure (CNKI, www.cnki.net), Wanfang Data (www.wanfangdata.com) and Weipu Information (www.cqvip.com), with the terms "COVID-19", "designated hospital" "Hubei-assisted", "makeshift hospital”, "nursing”, "nursing shift”, "wholesystem takeover" and variations of these, in the title and abstract fields and the Boolean combinations of these words as the retrieval strategy (Table 1). The type of literature was limited to journal article. The full texts of
Table I Search Strategy for Retrieval of Chinese Literature on Nursing Scheduling Mode and Experience from the Medical Team in Aiding Hubei Province During the COVID-19 Outbreak

\begin{tabular}{|l|l|}
\hline Search & \multicolumn{1}{|c|}{ Query } \\
\hline$\# I$ & $\begin{array}{l}\text { COVID-I9[tiab] OR the novel coronavirus[tiab] OR the } \\
\text { coronavirus outbreak[tiab] }\end{array}$ \\
\hline$\# 2$ & $\begin{array}{l}\text { Hubei assisted[all fields] OR aid of Hubei[all fields] OR aid } \\
\text { of Wuhan[all fields] OR E-assisted[all fields] OR medical } \\
\text { teams in assisting Wuhan[all fields] }\end{array}$ \\
\hline$\# 3$ & $\begin{array}{l}\text { Nursing[all fields] OR nurses[all fields] OR nursing shift[all } \\
\text { fields] OR nursing management[all fields] OR management } \\
\text { mode[all fields] OR reorganization system[all fields] }\end{array}$ \\
\hline$\# 4$ & $\begin{array}{l}\text { Designated hospital[tiab] OR makeshift hospital[tiab] OR } \\
\text { whole system takeover[tiab] }\end{array}$ \\
\hline$\# 5$ & (\#I AND \#2 AND \#3) OR \#4 \\
\hline
\end{tabular}

all related publications were downloaded. Two independent researchers (X.Z. and D.H.) screened the downloaded articles manually according to inclusion and exclusion criteria after reviewing the titles and abstracts and the full text. The references of the downloaded articles were also manually screened for relevant studies. If there were considerable discrepancies, the principal investigator ( $\mathrm{P}$. G.) would judge whether an article met the inclusion criteria.

\section{Inclusion and Exclusion Criteria}

Observational or self-controlled studies were eligible for the inclusion if they could satisfy the following criteria, (i) they were studies providing nursing scheduling mode and experience from the medical teams in aiding Hubei Province during the COVID-19 outbreak; (ii) they provided the type of the hospital or ward assisted; (iii) they provided the type of aiding mode (whole-system takeover or joint management); (iv) they provided the characteristics of nursing team involved. Regarding the exclusion criteria, case reports and case series, review articles, letters to the editor, the articles that only with ambiguous information of nursing shift and studies providing duplicated information in the same ward and nursing team were excluded.

\section{Information Extraction}

After the downloaded full texts were extracted and doublechecked, the following eligibility items and information were collected and recorded for each included study: first 
author, journal, date of submission, author's identity (nurses aiding epidemic control in Hubei or local nurses in Hubei), date of medical team dispatched to aid Hubei, type of hospital or ward assisted (designated hospital or makeshift hospital) and the mode of aid (whole-system takeover or joint management), characteristics of nursing team involved, nursing shift length, adjustment information, the reasons for the adjustment and the subsequent effects of the adjustment (if available), type of study to measure each work shift (observational study or selfcontrolled study). In this process, those events that caused nurses to be unable to perform nursing tasks and some work-friendly measures were also extracted. To ensure the reliability, two investigators (X.Z. and D.H.) independently summarized the data before discussing the results together, and all the discrepancies resolved by the principal investigator (P.G.).

\section{Results}

\section{Data Acquisition and Characteristics of the Included Studies}

Based on the pre-defined search strategy and the inclusion and exclusion criteria, altogether, 17 journal articles have been included in the target field (Table 2). The literature selection process is presented in Figure 1. ${ }^{12}$ These 17 articles scattered in 15 kinds of journals, these journals could be grouped into three categories, nursing (eight kinds of journals), clinical medicine, including general medicine, critical care medicine and disaster medicine (five kinds of journals), and hospital management (two kinds of journals). Among the articles, there are 12 articles with all the authors were nurses aiding epidemic control in Hubei, there are four articles published by the nurses aiding epidemic control in Hubei

Table 2 Time of Providing Aid to Hubei, Article Submission Time and Journal Distribution in the Included Studies

\begin{tabular}{|c|c|c|c|c|}
\hline Included Studies & Author's Identity & $\begin{array}{c}\text { Date of Medical Team } \\
\text { Dispatched to Aid Hubei }\end{array}$ & $\begin{array}{c}\text { Article Submission } \\
\text { Date }\end{array}$ & Type of Journal \\
\hline Chen Q $2020^{14}$ & Nurses aiding epidemic control in Hubei & I4 February, 2020 & 03 March 2020 & Nursing professional journal \\
\hline Gao S $2020^{15}$ & Nurses aiding epidemic control in Hubei & 09 February 2020 & 20 March 2020 & Nursing professional journal \\
\hline Guo Q $2020^{16}$ & Hubei local nurses in host hospital & Not mentioned & 02 April 2020 & Nursing professional journal \\
\hline Kong R $2020^{17}$ & Nurses aiding epidemic control in Hubei & 13 February 2020 & 25 March 2020 & Medical professional journal \\
\hline Liu Y $2020^{18}$ & Nurses aiding epidemic control in Hubei & 25 January 2020 & I5 May 2020 & Nursing professional journal \\
\hline Lu J $2020^{19}$ & $\begin{array}{l}\text { Nurses aiding epidemic control in Hubei } \\
\text { \& Hubei local nurses }\end{array}$ & 14 February 2020 & 02 March 2020 & Medical professional journal \\
\hline Luo C $2020^{20}$ & $\begin{array}{l}\text { Nurses aiding epidemic control in Hubei } \\
\qquad \& \text { Hubei local nurses }\end{array}$ & 13 February 2020 & 22 April 2020 & Nursing professional journal \\
\hline Nie J $2020^{21}$ & Nurses aiding epidemic control in Hubei & 24 January 2020 & 05 June 2020 & Nursing professional journal \\
\hline Peng $\times 2020^{13}$ & Nurses aiding epidemic control in Hubei & 26 January 2020 & 10 February 2020 & Nursing professional journal \\
\hline Shen P $2020^{22}$ & Nurses aiding epidemic control in Hubei & February 2020 & 14 March 2020 & Medical professional journal \\
\hline Wu Y $2020^{23}$ & Nurses aiding epidemic control in Hubei & Not mentioned & 15 March 2020 & Nursing professional journal \\
\hline Xiao Y $2020^{24}$ & $\begin{array}{l}\text { Nurses aiding epidemic control in Hubei } \\
\qquad \& \text { Hubei local nurses }\end{array}$ & Not mentioned & 26 February 2020 & $\begin{array}{l}\text { Hospital management related } \\
\text { journal }\end{array}$ \\
\hline Ye L $2020^{25}$ & $\begin{array}{l}\text { Nurses aiding epidemic control in Hubei } \\
\qquad \& \text { Hubei local nurses }\end{array}$ & Not mentioned & 10 March 2020 & Nursing professional journal \\
\hline Zhang L $2020^{26}$ & Nurses aiding epidemic control in Hubei & Not mentioned & II March 2020 & Nursing professional journal \\
\hline Zhang Y $2020^{27}$ & Nurses aiding epidemic control in Hubei & 28 January 2020 & 27 February 2020 & Medical professional journal \\
\hline Zheng J $2020^{28}$ & Nurses aiding epidemic control in Hubei & Not mentioned & $\begin{array}{c}\text { Between } 25 \text { March } 2020 \\
\text { and } 20 \text { April }\end{array}$ & $\begin{array}{l}\text { Hospital management related } \\
\text { journal }\end{array}$ \\
\hline Zheng $X 2020^{29}$ & Nurses aiding epidemic control in Hubei & 24 January 2020 & 20 February 2020 & Medical professional journal \\
\hline
\end{tabular}



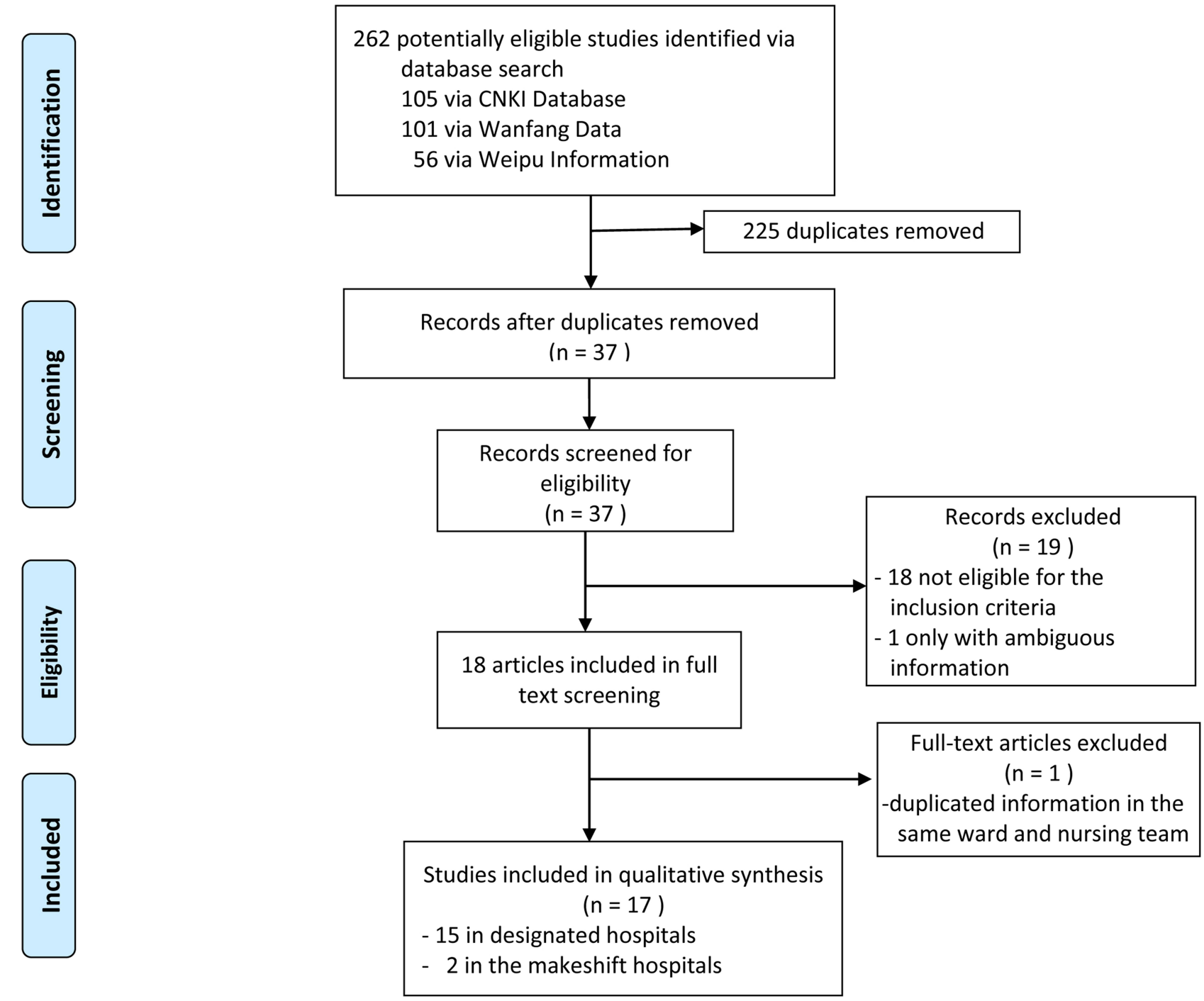

Figure I The preferred reporting items for systematic reviews and meta-analyses flow diagram. Adapted from Moher D, Liberati A, Tetzlaff J, Altman DG; PRISMA Group. Preferred reporting items for systematic reviews and meta-analyses: the PRISMA statement. PLoS Med. 2009;6(7):el000097. ${ }^{12}$

and the nurses in Hubei local hospitals, there is one article written by Hubei local nurses. According to the available information regarding the dispatch date of aiding Hubei and the date of article submission, the fastest article was summarized and submitted within 15 days after aiding Hubei, ${ }^{13}$ this article was also the earliest submission (Table 2).

\section{Nursing Shift Length and Adjustment in the Included Studies}

Among the included 17 studies, 15 medical teams provided medical assistance in designated hospitals and the other two medical teams worked in the makeshift hospitals (Table 3); among these 17 studies, 16 medical teams worked in Wuhan City, the capital city in Hubei
Province, and one medical team worked in a county-level designated hospital in Huanggang City. ${ }^{17}$ Regarding the distribution of management mode, two studies indicated joint nursing management, ${ }^{16,24}$ and the rest 15 studies presented the whole-system takeover mode (Table 3).

Among the included 17 studies, six studies indicated clear adjustment of nursing schedule mode and subsequent effect of the adjustment (Table 3). ${ }^{13,17,21,22,28,29}$ Most medical teams worked in a three-zone environment (contaminated area, ie red zone; potentially contaminated area, ie yellow zone; clean area, ie green zone), and one medical team ${ }^{20}$ had to work in a two-zone environment (contaminated area, ie red zone; relatively clean area, ie green zone) under the limitations of the original layout of the hospital building. 
Table 3 Nursing Shift Length and Adjustment Provided by the Medical Teams in Aiding Hubei Province During the COVID-I9 Outbreak

\begin{tabular}{|c|c|c|c|}
\hline $\begin{array}{l}\text { Included } \\
\text { Studies }\end{array}$ & $\begin{array}{l}\text { Type of Hospital } \\
\text { or Ward Assisted } \\
\text { and the Mode of } \\
\text { Aid }\end{array}$ & $\begin{array}{l}\text { Characteristics of } \\
\text { Nursing Team } \\
\text { Involved }\end{array}$ & Type of Study, Shift Length, Adjustment and Effects \\
\hline $\begin{array}{l}\text { Chen } \\
\text { Q } 2020^{14}\end{array}$ & $\begin{array}{l}\text { Designated hospital, } \\
\text { whole-system } \\
\text { takeover }\end{array}$ & $\begin{array}{l}91 \text { nurses from } 39 \\
\text { hospitals in Fujian } \\
\text { Province }\end{array}$ & $\begin{array}{l}\text { Observational study. } \\
\text { 4-hour (h) shift, work-rest balanced mode, flexible scheduling according to nursing workload (in the } \\
\text { afternoon and evening shifts during peak hours for admission of patients, I-3 additional standby } \\
\text { nurses; during the peak discharge period, reduce the number of standby nurses according to the real- } \\
\text { time workload) }\end{array}$ \\
\hline $\begin{array}{l}\text { Gao } \\
\text { S } 2020^{15}\end{array}$ & $\begin{array}{l}\text { Designated hospital, } \\
\text { whole-system } \\
\text { takeover }\end{array}$ & $\begin{array}{c}100 \text { nurses from } \\
\text { Shandong Province }\end{array}$ & $\begin{array}{l}\text { Observational study. } \\
\text { Dynamic scheduling based on workload, flexible scheduling based on working hours, workload and the } \\
\text { number of critically ill patients admitted, humanized scheduling based on the daily reported health } \\
\text { status of the nurses, and professional-integrated scheduling according to the professional distribution } \\
\text { of nurses on the basis of four-hour shift length }\end{array}$ \\
\hline $\begin{array}{l}\text { Guo } \\
\text { Q } 2020^{16}\end{array}$ & $\begin{array}{l}\text { Intensive Care Unit } \\
\text { in designated } \\
\text { hospital, joint } \\
\text { management }\end{array}$ & $\begin{array}{l}100 \text { nurses from } \\
\text { other provinces, } 25 \\
\text { local nurses }\end{array}$ & $\begin{array}{l}\text { Observational study. } \\
\text { 4-h shift for responsible nurses aiding Hubei, 6-h shift for local nurses from host hospital assisting in } \\
\text { communication and handling of medical advice and other administrative matters }\end{array}$ \\
\hline $\begin{array}{l}\text { Kong } \\
\text { R 202017 }\end{array}$ & $\begin{array}{l}\text { County-level } \\
\text { designated hospital, } \\
\text { whole-system } \\
\text { takeover }\end{array}$ & $\begin{array}{l}35 \text { nurses from } 7 \\
\text { hospitals in Shandong } \\
\text { Province }\end{array}$ & $\begin{array}{l}\text { Self-controlled study. } \\
\text { Humanized scheduling, at the beginning, special considerations for ensuring sufficient nursing } \\
\text { manpower and protection safety; } \\
\text { In the later stage, stepwise progressive scheduling mode with considerations for senior-junior } \\
\text { cooperation and group-fixed arrangement } \\
\text { Effects: no complaints about nursing service, no accidents in nursing quality, and no infection among } \\
\text { nursing staff. }\end{array}$ \\
\hline $\begin{array}{l}\text { Liu } \\
\text { Y } 2020^{18}\end{array}$ & $\begin{array}{l}\text { Designated hospital, } \\
\text { whole-system } \\
\text { takeover }\end{array}$ & $\begin{array}{l}93 \text { nurses from } \\
\text { Zhejiang Province }\end{array}$ & $\begin{array}{l}\text { Observational study. } \\
\text { 4-h shift from } 8 \text { a.m. to } 8 \text { a.m. the next day, } 5 \text { nurses/group per shift during daytime, } 3 \text { nurses/group per } \\
\text { shift at night }\end{array}$ \\
\hline $\begin{array}{l}\text { Lu } \\
\text { J } 2020^{19}\end{array}$ & $\begin{array}{l}\text { Intensive Care Unit } \\
\text { in designated } \\
\text { hospital, whole- } \\
\text { system takeover }\end{array}$ & $\begin{array}{l}99 \text { nurses from } \\
\text { Zhejiang Province }\end{array}$ & $\begin{array}{l}\text { Observational study. } \\
\text { 4-h shift, nurse-patient ratio: 1:5 1:8 for moderate COVID-19 patients; 1:3 1:5 for severe patients; } \\
\text { I:I I:3 for critically ill patients, I-2 standby nurses for each shift }\end{array}$ \\
\hline $\begin{array}{l}\text { Luo } \\
\text { C } 2020^{20}\end{array}$ & $\begin{array}{l}\text { Designated hospital, } \\
\text { whole-system } \\
\text { takeover }\end{array}$ & $\begin{array}{l}50 \text { nurses from the } \\
\text { military medical team }\end{array}$ & $\begin{array}{l}\text { Observational study. } \\
\text { 4-h shift, within } 2 \text { to } 3 \text { hours for the first time working in the contaminated area; fixed arrangement of } \\
6 \text { nurses/group }\end{array}$ \\
\hline $\begin{array}{l}\mathrm{Nie} \\
\text { J } 2020^{21}\end{array}$ & $\begin{array}{l}\text { Designated hospital, } \\
\text { whole-system } \\
\text { takeover }\end{array}$ & $\begin{array}{l}80 \text { nurses from the } \\
\text { armed force }\end{array}$ & $\begin{array}{l}\text { Self-controlled study. } \\
\text { Preliminary schedule: } 4 \text {-h shift from } 9 \text { a.m. to } 9 \text { a.m. the next day, } 8 \text { responsible nursing groups rotating } \\
\text { in turn. } \\
\text { After adjustment: } 4 \text {-h shift, fixed work shift sequence, } 8 \text { days as a rotation cycle thus one day off after } \\
\text { the } 3 \text { rd shift and the } 7 \text { th shift } \\
\text { Effect: The three fixed shifts of each nursing group in each rotation cycle improved the proficiency and } \\
\text { work efficiency of nursing work, and reduced the psychological burden of nursing staff; between two } \\
\text { shifts in each group, } 4 \text { hours of rest time was added, and thus the effective rest time could reach } 18 \text { to } \\
20 \text { hours. }\end{array}$ \\
\hline $\begin{array}{l}\text { Peng } \\
\times 2020^{13}\end{array}$ & $\begin{array}{l}\text { Designated hospital, } \\
\text { whole-system } \\
\text { takeover }\end{array}$ & $\begin{array}{l}48 \text { nurses from the } \\
\text { military medical team }\end{array}$ & $\begin{array}{l}\text { Self-controlled study. } \\
\text { Preliminary schedule: 2-h shift, special considerations for personnel adaptation, environmental adaptation, } \\
\text { collaboration; } \\
\text { After adjustment: 3-h shift, special considerations for morning/evening shift and the rescue period } \\
\text { Effect: the scheduling design and adjustment improved the overall scheduling satisfaction of nurses and thus } \\
\text { provided a good foundation for human resources protection. }\end{array}$ \\
\hline
\end{tabular}

(Continued) 
Table 3 (Continued).

\begin{tabular}{|c|c|c|c|}
\hline $\begin{array}{l}\text { Included } \\
\text { Studies }\end{array}$ & $\begin{array}{l}\text { Type of Hospital } \\
\text { or Ward Assisted } \\
\text { and the Mode of } \\
\text { Aid }\end{array}$ & $\begin{array}{l}\text { Characteristics of } \\
\text { Nursing Team } \\
\text { Involved }\end{array}$ & Type of Study, Shift Length, Adjustment and Effects \\
\hline $\begin{array}{l}\text { Shen } \\
\text { P } 2020^{22}\end{array}$ & $\begin{array}{l}\text { Designated hospital, } \\
\text { whole-system } \\
\text { takeover }\end{array}$ & $\begin{array}{l}102 \text { nurses from the } \\
\text { military medical team }\end{array}$ & $\begin{array}{l}\text { Self-controlled study. } \\
\text { Preliminary schedule: 4-h shift in progressive scheduling mode. } \\
\text { After adjustment: 4-h shift in rolling scheduling mode. } \\
\text { Effect: the nurse staff could get a timely rest, the damage to sleep was minimized, and thus the body's } \\
\text { tolerance and resistance were improved. }\end{array}$ \\
\hline $\begin{array}{l}\text { Wu } \\
\text { Y } 2020^{23}\end{array}$ & $\begin{array}{l}\text { Makeshift hospital, } \\
\text { whole-system } \\
\text { takeover }\end{array}$ & $\begin{array}{l}100 \text { nurses from } \\
\text { Xinjiang Uygur } \\
\text { Autonomous Region }\end{array}$ & $\begin{array}{l}\text { Observational study. } \\
\text { 6-h shift from } 8 \text { a.m. to } 8 \text { a.m. the next day }\end{array}$ \\
\hline $\begin{array}{l}\text { Xiao } \\
\text { Y } 2020^{24}\end{array}$ & $\begin{array}{l}\text { Designated hospital, } \\
\text { joint management }\end{array}$ & $\begin{array}{c}93 \text { nurses from } \\
\text { national medical team, } \\
15 \text { nurses from host } \\
\text { hospital }\end{array}$ & $\begin{array}{l}\text { Observational study. } \\
\text { 4-h shift, } 6 \text { nurses/group per shift during daytime, } 4 \sim 5 \text { nurses/group per shift at night }\end{array}$ \\
\hline $\begin{array}{l}\text { Ye } \\
\text { L } 2020^{25}\end{array}$ & $\begin{array}{l}\text { Makeshift hospital, } \\
\text { whole-system } \\
\text { takeover }\end{array}$ & $\begin{array}{l}200 \text { nurses from } \\
\text { Anhui Province }\end{array}$ & $\begin{array}{l}\text { Observational study. } \\
\text { 6-h shift from } 8 \text { a.m. to } 8 \text { a.m. the next day }\end{array}$ \\
\hline $\begin{array}{l}\text { Zhang } \\
\text { L } 2020^{26}\end{array}$ & $\begin{array}{l}\text { Intensive Care Unit } \\
\text { in designated } \\
\text { hospital, whole- } \\
\text { system takeover }\end{array}$ & $\begin{array}{l}120 \text { nurses from } 7 \\
\text { hospitals in Tianjin } \\
\text { City }\end{array}$ & $\begin{array}{l}\text { Observational study. } \\
\text { 4-h shift with senior nurses take care of severe and critically ill patients }\end{array}$ \\
\hline $\begin{array}{l}\text { Zhang } \\
\text { Y } 2020^{27}\end{array}$ & $\begin{array}{l}\text { Designated hospital, } \\
\text { whole-system } \\
\text { takeover }\end{array}$ & $\begin{array}{l}19 \text { nurses from Gansu } \\
\text { Province }\end{array}$ & $\begin{array}{l}\text { Observational study. } \\
\text { 6-h shift from } 8 \text { a.m. to } 8 \text { a.m. the next day, with 7, 5, } 5 \text { and } 3 \text { nurses per shift }\end{array}$ \\
\hline $\begin{array}{l}\text { Zheng } \\
\text { J } 2020^{28}\end{array}$ & $\begin{array}{l}\text { Intensive Care Unit } \\
\text { in designated } \\
\text { hospital, whole- } \\
\text { system takeover }\end{array}$ & $\begin{array}{l}100 \text { nurses from } \\
\text { Beijing City }\end{array}$ & $\begin{array}{l}\text { Self-controlled study. } \\
\text { Preliminary schedule: 6-h shift. } \\
\text { After adjustment: 4-h shift } \\
\text { Effect: the nurses' job satisfaction was increased }\end{array}$ \\
\hline $\begin{array}{l}\text { Zheng } \\
\times 2020^{29}\end{array}$ & $\begin{array}{l}\text { Designated hospital, } \\
\text { whole-system } \\
\text { takeover }\end{array}$ & $\begin{array}{c}82 \text { nurses from } 9 \\
\text { hospitals in } \\
\text { Guangdong Province }\end{array}$ & $\begin{array}{l}\text { Self-controlled study. } \\
\text { Preliminary schedule: } 4 \text {-h shift, the quota of nurses was allocated to the assisted medical teams from } \\
\text { each hospital ( } 9 \text { hospitals in total). } \\
\text { After adjustment: 4-h shift, group-fixed arrangement (nurses in one group from at most I or } 2 \\
\text { hospitals) } \\
\text { Effect: nursing work more smoothly and cooperate more tacitly. }\end{array}$ \\
\hline
\end{tabular}

Note: Designated hospital for COVID-19 patients.

In the makeshift hospitals that mainly treated mild COVID19 patients, six-hour (h) shift was adopted; while in the designated hospitals, four kinds of shift length, $2-\mathrm{h},{ }^{13} 3-\mathrm{h},{ }^{13} 4-\mathrm{h}$ and $6-\mathrm{h}^{23,25,27,28}$ shift have been considered (Table 3). For the shift rotation mode, it has been indicated that the mode of rotating in turn was adopted first and then was modified to fixed work shift sequence to provide the nurses an extra four hours' rest between two work shifts. Flexible scheduling and humanized scheduling were indicated in all the included 17 studies. Nine articles recommended the relatively fixed-grouping of nurses in the nursing management. ${ }^{13,14,17,19-22,26,29}$

\section{Events with Impact on Nurses' Work and Some Work-Friendly Measures}

In the 17 included studies, the events that have been reported to have an impact on the nurses' work and life mainly include the psychological stress, ${ }^{15-17,20,23,24}$ facial pressure injuries from wearing personal protective equipment, ${ }^{13,20}$ female menstrual period ${ }^{18}$ and the symptoms of chest tightness, dizziness, nausea under the threelevel protective measures. ${ }^{15,19,20}$ The specific solutions mentioned include the clarification of job responsibilities as detailed as possible, ${ }^{15,20,24}$ the deployment of 
psychologist in the medical team, ${ }^{16}$ timely statistics of nurses' extra shift and extra working hours and timely arrangement of compensatory time off, ${ }^{17}$ preparing obvious labels or identifications for various items and medicines, ${ }^{21,26}$ the optimization of the placement and location of items, especially the placement of the items in the upper cabinet which can reduce the number of squatting and standing posture conversions, ${ }^{21}$ those solutions have been proved to save working time and reduce the nursing workload. In the composition of each nursing team, the following composition has been considered and put into practice, each nursing team was equipped with one to two nurses with intensive care or respiratory care experience, ${ }^{19,28}$ in the intensive care unit, at least one nurse in each nursing shift could operate the ventilator proficiently, ${ }^{26}$ at least one to two male nurses in each nursing shift. ${ }^{20}$ Additionally, in each nursing team, the composition of senior and junior nurses was also considered. $^{15,16,23,27-29}$ In terms of emotional motivation, the organization of activities during the time of traditional festivals and medical team members' birthdays has also been proved helpful to improve the quality of work life in the fast-paced working environment of cross-regional medical assistance. ${ }^{17,28}$

\section{Discussion}

In the context of COVID-19 outbreak and epidemic status, the nurses from across the country to aid Hubei have encountered the vast challenges. Their roles were not only the nurses, but also the care workers, cleaners and porters, they needed to undertake the extra tasks of disinfection, isolation and item handling. ${ }^{30-32}$ Thus, in this situation, timely summarizing the existing frontline experience in managing the human resources and the scheduling mode can contribute to improve the nurses' job satisfaction and the quality of nursing services. ${ }^{33}$ The scheduling mode in designated hospital that presented in the included studies could be summarized as

Dynamic scheduling based on workload, flexible scheduling based on working hours, workload and the number of critically ill patients admitted, humanized scheduling based on the daily reported health status of the nurses, and professional-integrated scheduling according to the professional distribution of nurses on the basis of fourhour shift length. (abbreviated as 4-h shift based DFHPI scheduling strategy).
And in makeshift hospital, the corresponding scheduling mode was "6-h shift based DFHPI scheduling".

The efficient work of nurses after arriving in Hubei contributed a lot to shorten the long waiting list of COVID-19 patients and deal with the short-term crisis in Hubei province. Some medical teams first chose the 6-h shift mode from the perspective of treating more patients as soon as possible, and some other medical teams first chose the $2-\mathrm{h}^{13}$ or $3-\mathrm{h}^{13}$ shift mode from the perspective of improving the adaptability of nurses. Subsequently, they all adjusted the shift length according to the severity of the condition of the admitted COVID-19 patients, the adaptation of the nurses and the peak number of admitted patients or discharged patients. Professional integrated scheduling indicated that the nurse leaders had to conduct the baseline survey of the nurses' professional background, age, education level and work experience before grouping. All the shift length-related adjustment decisions required the nurse leaders to have a good knowledge of not only the distribution of disease severity among the admitted patients, but also to understand the professional background and dynamic personal physical condition and emotional stress of the responsible nurses. ${ }^{34}$ In the era of COVID-19, it has been reported that the recognition of the leadership style, organizational culture and model of successful implementation are inextricable is the first step to guarantee sustainable interventions to support healthcare workers' well-being will follow. ${ }^{35}$

In terms of working hours in each shift, from February to March, 2020, one questionnaire-based cross-sectional survey has been conducted among 109 nurses who have worked in 10 designated hospitals providing treatments to patients with COVID-19 in China. ${ }^{36}$ In the survey, $60.55 \%$ $(66 / 109)$ of the nurses regarded four hours as the preferred number of work hours per shift and it has been identified that the circumstances, personal preventable equipment, the nurses' physical and emotional needs of nurse, and the nurses' safety needs and work intensity are the main influencing factors associated with gap between the actual work hours and the nurses preferred work hours. ${ }^{36}$

The topic discussed in the present study is the crossregional medical assistance in the same country in the face of major public health emergencies, in the early days of the COVID-19 outbreak and epidemic. ${ }^{37}$ The authors clearly understand that in the real world, it is difficult to provide recommendations or solutions that could fit all medical institutions, owing to the major differences between them in terms of the total number of beds including ICU capacity, 
the availability of hospital resources and the severity of admitted COVID-19 patients in each country or region. It can be inferred that if in the context of cross-border medical assistance, the jet lag, different standards of medical devices, labeling issues on various kinds of drugs and the language issues between the medical teams from different countries and local people will pose considerable challenges. In the future, there are more things that can be done to improve the nursing management. ${ }^{38,39}$ Continuous scientific arrangement of nursing shifts, simpler checklist, better interpretation of the nursing management plan, smarter equipment for monitoring and evaluating the nursing workload or physical conditions of nurses would be helpful to improve the nurses' job satisfaction and the quality of nursing, reduce the work intensity and work stress of the nurses. ${ }^{40-42}$

This present systematic review has several potential limitations which may encourage further research efforts. First, 16 of the 17 included studies introduced the work in Wuhan city, and only one article reported the status in Huanggang city. The reports on the nursing management situation in other cities in Hubei Province will be further collected. Second, the generalizability of the protocols or nursing scheduling modes provided in the included studies could not be judged or evaluated. Third, due to time constraints or other reasons, only a small part of nurses that have provided assistance to Hubei summarized their nursing scheduling experience in the format of journal article. The experience that might nest in the newspaper and video interview will be further explored and collected.

\section{Conclusion}

The descriptive results of the present systematic review shed light on the challenges and practical solutions of nursing scheduling mode in the context of cross-regional medical assistance. Additionally, the present systematic review could provide the academic community of nurses, nurse managers and administrators with baseline information and scientific productions from the content's points of view in the target field.

\section{Acknowledgments}

This work was supported by the National Natural Science Foundation of China (Grant No. 71974199), the Science Foundation of Liaoning Provincial Department of Education of China (JCRW2020002), the Liaoning Natural Science Foundation of China (2020-MS-159 and 2019-ZD -0770) and China Medical University COVID-19 Prevention and Control Related Research Fund (CMU-K-[2020]12).
The findings and conclusions in this review are those of the authors and the funders had no role in study design, data collection and analysis, decision to publish, or preparation of the manuscript.

\section{Disclosure}

The authors declare no conflicts of interest in this work.

\section{References}

1. The State Council Information Office of the People's Republic of China. Fighting Covid-19 China in Action. Beijing, China: Foreign Languages Press; 2020:1-50.

2. Liu Q, Luo D, Haase JE, et al. The experiences of health-care providers during the COVID-19 crisis in China: a qualitative study. Lancet Glob Health. 2020;8(6):e790-e798. doi:10.1016/S2214-109X(20)30204-7

3. Liu Y, Wang H, Chen J, et al. Emergency management of nursing human resources and supplies to respond to coronavirus disease 2019 epidemic. Int J Nurs Sci. 2020;7:135-138. doi:10.1016/j.ijnss.2020.03.011

4. Moloney W, Fieldes J, Jacobs S. An Integrative review of how Healthcare Organizations can support hospital nurses to thrive at work. Int $J$ Environ Res Public Health. 2020;17(23):E8757. doi:10.3390/ijerph17238757

5. Aloustani S, Atashzadeh-Shoorideh F, Zagheri-Tafreshi M, Nasiri M, Barkhordari-Sharifabad M, Skerrett V. Association between ethical leadership, ethical climate and organizational citizenship behavior from nurses' perspective: a descriptive correlational study. $B M C$ Nurs. 2020;19:15. doi:10.1186/s12912-020-0408-1

6. Wlody GS. Nursing management and organizational ethics in the intensive care unit. Crit Care Med. 2007;35(2 Suppl):S29-S35. doi:10.1097/01.CCM.0000252910.70311.66

7. Garcia-Garcia I, Ramos VB, Serrano JL, Ramos Cobos MC, Souza A. Nursing personnel's perceptions of the organizational climate in public and private hospitals in Spain. Int Nurs Rev. 2011;58:234-241. doi:10.1111/j.1466-7657.2010.00871.x

8. Zhan Y, Liu Y, Liu H, et al. Factors associated with insomnia among Chinese front-line nurses fighting against COVID-19 in Wuhan: a cross-sectional survey. $J$ Nurs Manag. 2020;28(7):1525-1535. doi:10.1111/jonm.13094

9. Zhan YX, Zhao SY, Yuan J, et al. Prevalence and influencing factors on fatigue of first-line nurses combating with COVID-19 in China: a Descriptive Cross-Sectional Study. Curr Med Sci. 2020;40 (4):625-635. doi:10.1007/s11596-020-2226-9

10. Gao X, Jiang L, Hu Y, Li L, Hou L. Nurses' experiences regarding shift patterns in isolation wards during the COVID-19 pandemic in China: a qualitative study. J Clin Nurs. 2020;29(21-22):4270-4280. doi:10.1111/jocn.15464

11. Gordon A, Lyons C, Rao S, Finoli L. Health care workers' challenges in the care of a COVID-19 patient. Crit Care Nurs Q. 2020;43 (4):400-406. doi:10.1097/CNQ.0000000000000325

12. Moher D, Liberati A, Tetzlaff J, Altman DG; PRISMA Group. Preferred reporting items for systematic reviews and meta-analyses: the PRISMA statement. PLoS Med. 2009;6(7):e1000097. doi:10.1371/journal.pmed.1000097

13. Peng X, Peng Y, Xiao L, Jin C, Liu L. Practice of step-by-step nursing scheduling mode in medical team of assisting Hubei Province. Nurs J Chin People Liberation Army. 2020;37(2):10-12. Article in Chinese. doi:10.3969/j.issn.1008-9993.2020.02.004

14. Chen Q, Chen M, Zheng Y, et al. Analysis of application effect of the reorganization system management mode in nursing management of coronavirus disease 2019 isolation ward. Chin J Nurs. 2020;55 (Suppl):241-243. Article in Chinese. doi:10.3761/j.issn.02541769.2020.S1.087 
15. Gao S, Tuo M, Wu Q, Sun W, Wang F, Wei L. Discussion on the nursing schedule mode of the medical team in aid to Hubei. Nurs Integr Tradit Chin West Med. 2020;6(4):135-136. doi:10.11997/ nitcwm.202003101

16. Guo Q, Chen L, Wang H, Yang L. Nursing management in joint ward for fighting against COVID-19. J Nurs Sci. 2020;35(19):72-73,78. Article in Chinese. doi:10.3870/j.issn.1001-4152.2020.19.072

17. Kong R, Ge S, Guo S, et al. Application of flexible management strategy in the management of nursing team in Hubei Province. $J$ Community Med. 2020;18(8):588-590. Article in Chinese. doi:10.19790/j.cnki.JCM.2020.08.09

18. Liu Y, Wang XY. Discussion on the management mode of the general ward and nursing staff of the new coronavirus pneumonia-based on the experience of the first batch of Zhejiang aided medical teams. Nurs Rehabil J. 2020;19(8):74-76. Article in Chinese. doi:10.3969/j. issn. 1671-9875.2020.08.020

19. Lu J, Ruan P, Wang Q, et al. Emergency nursing management experience of the reorganization of the medical aid team to take over the new coronavirus pneumonia isolation ward. Chin J Crit Care Med. 2020;13(2):128-130. Article in Chinese. doi:10.3877/ cma.j.issn.1674-6880.2020.02.010

20. Luo C, Tang T, Du X, et al. Frontline nursing management practice and experience from the military medical team in assisting COVID-19 specialized hospital in Wuhan. Chin Nurs Manage. 2020;20(9):1365-1369. Article in Chinese. doi:10.3969/j.issn.16721756.2020.09.017

21. Nie J, Ren J, Guo Y, Hou Y. Discussion on the working mode of nursing staff in the medical team of the armed police force in Hubei. Tianjin J Nurs. 2020;28(5):574-576. Article in Chinese. doi:10.3969/ j.issn.1006-9143.2020.05.021

22. Shen P, Feng X, Qian W, et al. Discussion on the nursing management system architecture and scheduling mode for batch treatment of patients with new coronavirus pneumonia. Chin J Disaster Med. 2020;8(4):209-211. Article in Chinese. doi:10.13919/j.issn.2095-6274.2020.04.010

23. Wu Y, Dai W, Xiong Y, Liu R, Zhang C. Nursing management and experience of coronavirus disease 2019 infection in Wuhan mobile cabin hospital. Chin J Nurs. 2020;55(Suppl):58-59. Article in Chinese. doi:10.3761/j.issn.0254-1769.2020.S1.021

24. Xiao Y, Zhang Q, Liu F, Yang L, Chen Y. Organization and management of COVID-19 treatment in a medical team assisting Wuhan. Hosp Adm J Chin People Liberation Army. 2020;27(5):412-414. Article in Chinese. doi:10.16770/J.cnki.1008-9985.2020.05.004

25. Ye L, Zhou J, Feng A. Management practice and thinking of makeshift hospitals during the new coronavirus pneumonia epidemic. Chin Gen Pract Nurs. 2020;18(9):1077-1079. Article in Chinese. doi:10.12104/j.issn.1674-4748.2020.09.016

26. Zhang L, Li M, Li J, Lin M. The practice and thinking of assisting Hubei medical team to take over the critical ward. Tianjin J Nurs. 2020;28(5):570-572. Article in Chinese. doi:10.3969/j.issn.10069143.2020.05.019

27. Zhang Y, Kong W, Chu X, et al. The first batch of E-assisted medical team's experience of nursing management on the COVID-19 isolation ward from Gansu. West J Tradit Chin Med. 2020;33(4):27-29. Article in Chinese. doi:10.12174/j.issn.1004-6852.2020.04.09
28. Zheng J, Zhang X, Zhu F, Wang L, Jiang B, Wang T. Discussion on management of critical care team in COVID-19 epidemic area. Hosp Manage Forum. 2020;37(4):29-31,37. Article in Chinese. doi:10.3969/j.issn.1671-9069.2020.04.007

29. Zheng X, Zheng L, Yang Y, Yu T, Hu A. Discussion on the deployment and working mode of nursing staff in the formation of medical aid team for Hubei. Guangdong Med J. 2020;41(4):329-331. Article in Chinese. doi:10.13820/j.cnki.gdyx.20200489

30. Bambi S, Iozzo P, Lucchini A. New issues in nursing management during the COVID-19 pandemic in Italy. Am J Crit Care. 2020;29: e92-e93. doi:10.4037/ajec2020937

31. Fernandez R, Lord H, Halcomb E, et al. Implications for COVID-19: a systematic review of nurses' experiences of working in acute care hospital settings during a respiratory pandemic. Int J Nurs Stud. 2020;111:103637. doi:10.1016/j.ijnurstu.2020.103637

32. Jiang L, Broome ME, Ning C. The performance and professionalism of nurses in the fight against the new outbreak of COVID-19 epidemic is laudable. Int J Nurs Stud. 2020;107:103578. doi:10.1016/j. ijnurstu.2020.103578

33. Xiang YT, Li W, Zhang Q, et al. Timely research papers about COVID-19 in China. Lancet. 2020;395(10225):684-685. doi:10.1016/S0140-6736(20)30375-5

34. Zhan Y, Ma S, Jian X, et al. The current situation and influencing factors of job stress among frontline nurses assisting in Wuhan in fighting COVID-19. Front Public Health. 2020;8:579866. doi:10.3389/fpubh.2020.579866

35. Obrien N, Flott K, Durkin M. COVID-19: leadership on the frontline is what matters when we support healthcare workers. Int $J$ Qual Health Care. 2021;33(1):mzaa153. doi:10.1093/intqhe/mzaa153

36. Zhang X, Jiang Z, Yuan X, et al. Nurses reports of actual work hours and preferred work hours per shift among frontline nurses during coronavirus disease 2019 (COVID-19) epidemic: a cross-sectional survey. Int J Nurs Stud Adv. 2021;3:100026. doi:10.1016/j.ijnsa.2021.100026

37. Zhang W, Qian BY. Making decisions to mitigate COVID-19 with limited knowledge. Lancet Infect Dis. 2020;20(10):1121-1122. doi:10.1016/S1473-3099(20)30280-2

38. Du J, Mayer G, Hummel S, et al. Mental health burden in different professions during the final stage of the COVID-19 lockdown in China: Cross-sectional Survey Study. J Med Internet Res. 2020;22 (12):e24240. doi:10.2196/24240

39. Shoja E, Aghamohammadi V, Bazyar H, et al. Covid-19 effects on the workload of Iranian healthcare workers. BMC Public Health. 2020;20(1):1636. doi:10.1186/s12889-020-09743-w

40. Zhang H, Zhao Y, Zou P, et al. Explaining Organizational citizenship behavior among Chinese nurses combating COVID-19. Risk Manag Healthc Policy. 2021;14:979-986. doi:10.2147/RMHP.S292436

41. Kowalski MO, Basile C, Bersick E, et al. What do nurses need to practice effectively in the hospital environment? An integrative review with implications for nurse leaders. Worldviews Evid Based Nurs. 2020;17(1):60-70. doi:10.1111/wvn.12401

42. Shan Y, Shang J, Yan Y, et al. Mental workload of frontline nurses aiding in the COVID-19 pandemic: a latent profile analysis. $J A d v$ Nurs. 2021;77(5):2374-2385. doi:10.1111/jan.14769
Risk Management and Healthcare Policy

\section{Publish your work in this journal}

Risk Management and Healthcare Policy is an international, peerreviewed, open access journal focusing on all aspects of public health, policy, and preventative measures to promote good health and improve morbidity and mortality in the population. The journal welcomes submitted papers covering original research, basic science, clinical \& epidemiological studies, reviews and evaluations, guidelines, expert opinion and commentary, case reports and extended reports. The manuscript management system is completely online and includes a very quick and fair peer-review system, which is all easy to use. Visit http://www.dovepress.com/testimonials.php to read real quotes from published authors. 